\title{
Eocrinoids from the Cambrian Mantou Formation of Dalian, Liaoning
}

\author{
HUANG DiYing \\ State Key Laboratory of Palaeobiology and Stratigraphy, Nanjing Institute of Geology and Palaeontology, Chinese Academy of Sciences, \\ Nanjing 210008, China
}

Received May 8, 2012; accepted July 23, 2012; published online August 18, 2012

\begin{abstract}
Cambrian echinoderms, especially eocrinoids, have been reported recently from Guizhou and Yunnan provinces of China, such as the Kaili, Balang, and Guanshan faunas. The present paper reports abundant well-preserved eocrinoids from the Cambrian Mantou Formation of Dalian, Liaoning Province. This new discovery provides additional data on the early evolution of Echinodermata. It also gives us a clue as to where to seek the Cambrian soft-bodied fauna on the margin of the North China Platform.
\end{abstract}

Liaoning, Cambrian, Mantou Formation, eocrinoids, echinoderms

Citation: Huang D Y. Eocrinoids from the Cambrian Mantou Formation of Dalian, Liaoning. Chin Sci Bull, 2012, 57: 3855-3857, doi: 10.1007/s11434-012-5433-3

Echinoderms, mainly displaying a pentagonal, radiate body plan, represent the major group of Deuterostomia that lives on the sea bed in the present marine environment. Molecular biology indicates that the origin of echinoderms can be traced back to a billion years ago [1]. However, their premiddle Cambrian fossil record is extremely rare. A few examples are known from this period including helicoplacoids from the Poleta Formation, California, Unite States [2], and vetulocystids from the Chengjiang fauna [3]. These echinoderms are early, extinct forms bearing very unusual characters. A well-known echinoderm community, including eocrinoids and edrioasteroids, has been described from the famous Kaili fauna [4,5]. More eocrinoids have been found in older strata, such as the Balang fauna of Guizhou Province [6,7] and the Guangshan fauna of Yunnan Province [8,9]. Eocrinoids are a relatively primitive group of Echinodermata and they are dominant among the Cambrian echinoderms. They are widespread on the margin of the continental shelf [10] in Europe, North America, Siberia, and China. They are mainly found in the middle and late Cambrian and Ordovician.

Some trilobite fragments and a few eocrinoids were first found by some local fossil enthusiasts (e.g. Mr. Tang Mao-

email: huangdiying@sina.com long) from a Cambrian section in the Jinshitan area. Abundant eocrinoids were found later during our field work with a total of 210 individuals discovered. These fossils are from the amaranthine calcareous mudstone of the Cambrian Mantou Formation (Qiandong Series) of the Jinshitan area, Dalian City, Liaoning Province, Northeast China. The locality represents the clinothem facies of the margin of the North China Platform. Abundant trilobite fragments (Redlichia murakamii; Figure 1(b),(c),(f)) and some brachiopods occur with the eocrinoids. This stratum belongs to the Redlichia (Pteroredlichia) chinensis Zone of the Duyun Stage which corresponds to the former lower part of the Longwangmiao Stage [11]. The assemblage is slightly later than the Balang and Guanshan faunas, but earlier than the Kaili fauna $[12,13]$. The representative trilobite species $R$. murakamii has been also reported from the Qingxudong Formation at Meitan, Guizhou Province, Longwangmiao Formation at Yiliang, Yunnan Province, and Shipai Formation at Yichang, Hubei Province [14]. In addition, some soft-bodied animal have also been reported from the Shipai Formation [15].

The eocrinoids reported herein are relatively small in size. They are normally less than $2 \mathrm{~cm}$ long (excluding brachioles). Some of them show that they were attached to trilobite fragments, as is the case at other localities, such as in 
the Kaili fauna [16]. These eocrinoids are divided into three parts comprising brachioles, a theca and a stalk. Brachioles are located at the apex of the theca, are not very elongate, and formed of many small plates. The number of brachioles is not easy to determine, but it is clearly more than five. The theca is of reverse conical shape, formed of simple and nearly elliptical small plates. The stalk is relatively long, thick, and tapered. A distinct boundary between the theca and stalk is absent. A detailed description will be provided in future work.

These eocrinoids are preserved in a somewhat threedimensional condition. Normally only the theca and part of the brachioles and stalk are preserved. The stalk is seldom completely exposed (Figure 1(b),(d)). Most specimens are in lateral aspect (Figure 1(a)-(d)) with some in vertical preservation (Figure 1(a),(c)) which differs from the famous soft-bodied Burgess Shale, Kaili and Guanshan faunas $[4,9,17]$. The vertical preservation probably indicates that some of the eocrinoids are certainly autochthonous. Isolated plates are common at this locality but they are always still grouped together (Figure 1(e)), indicating relatively weak current activity as in some soft-bodied faunas [18]. No soft parts were preserved with these eocrinoids and no soft-bodied animal fossils were discovered at this locality. The associated animals were limited to trilobites (usually fragmentary, seldom complete) and brachiopods. Thus, rapid burial by mud flow is probably not the reason for the preservation of this community. Moreover, bioturbation is seldom seen in this layer, which is another possible reason for the good preservation of eocrinoids.

The exceptionally well preserved Cambrian faunas in China are mainly reported from the Yangtze Platform, such as the Chengjiang, Kaili, and Guanshan faunas. Only a few soft-bodied animal fossils are known from the North China Platform to date. A group of variegated clastic rocks are widely distributed in North China, namely the Mantou Formation formerly subdivided into the Mantou, Maozhuang, and Xuzhuang formations from bottom to top [19]. At many localities, the Mantou Formation has developments of very fine variegated mudstone and shale so it is possible that soft-bodied animals are preserved in it. Early in 1937, the non-mineralized arthropod Tuzoia was discovered in the

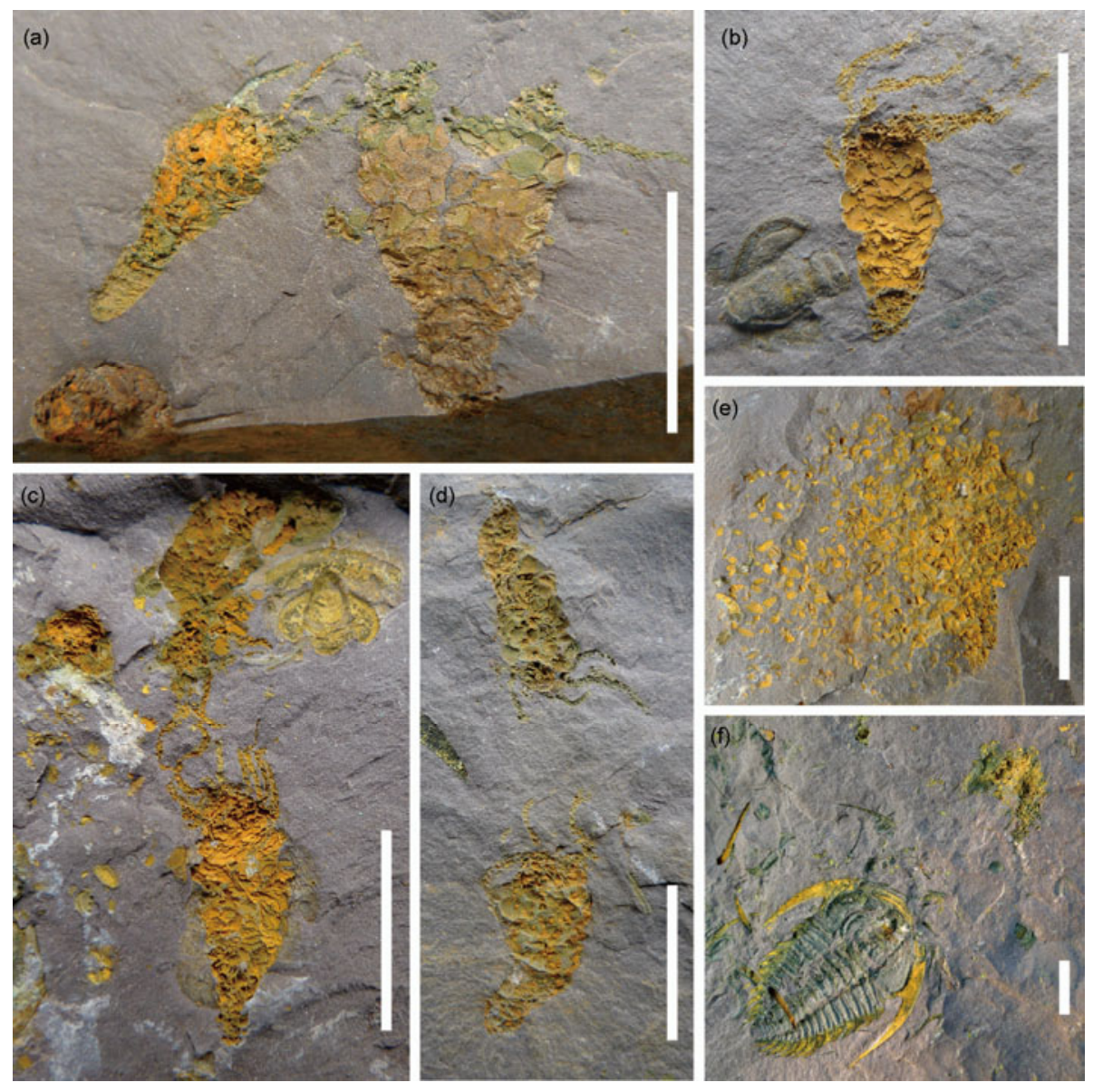

Figure 1 Eocrinoid fossils from the Mantou Formation at Dalian, Liaoning Province. Scale bars: $1 \mathrm{~cm}$. (a) Two laterally preserved specimens (NIGP154653 and NIGP154654) and a vertically preserved specimen (NIGP154655); (b) a small individual (NIGP154656) with rather well-preserved arms and a fixigena of the trilobite Redlichia murakamii; (c) two laterally preserved specimens (NIGP154657 and NIGP154658), a vertically preserved specimen (NIGP154659), and some isolated eocrinoid plates, preserved with the fixigena of R. murakamii; (d) two rather well-preserved specimens (NIGP154660 and NIGP154661); (e) some isolated eocrinoid plates (NIGP154662); (f) an almost complete R. murakamii preserved with an eocrinoid (NIGP154663). 
Mantou Formation at Benxi, Liaoning Province [20]. A palaeoscolecid worm is also known from the Mantou Formation at Huainan, Anhui Province [21]. In recent years, a new soft-bodied fauna has been found in the topmost Mantou Formation at Linyi, Shandong Province, with a new species of Isoxys [22]. The finds reported here suggest that Cambrian, non-mineralized exceptionally preserved fossils may also occur in the clinothem facies on the margin of the North China Platform. In contrast to soft-bodied animal fossils, eocrinoids are easier to preserve due to the relatively highly mineralized plates. However, the isolated plates are usually difficult to identify and are readily ignored. Here, the eocrinoids from Dalian comprise both complete individuals and isolated plates due to limited current activity. Eocrinoids have been widely reported from the Yangtze Platform in Yunnan and Guizhou provinces and may serve as a pointer to the Burgess Shale-type faunas. Research on the Cambrian of the Mantou Formation on the margin of the North China platform is still at a preliminary stage and has much future potential. This paper provides some useful information for future field work.

The author is grateful to Tang MaoLong for help with field work, Prof. Peng ShanChi (Nanjing Institute of Geology and Palaeontology) for indentifying the trilobites and providing literature, Cai ChenYang, Liao HuanYu, and Wang YuNan for field work and assistance, and Prof. Dr. E. Jarzembowski for checking the English. This work was supported by the National Natural Science Foundation of China (40872010) and the Key Research Program of the Chinese Academy of Sciences (KZZD-EW-02).
1 Wray G A, Levinton J S, Shapiro L H. Science, 1996, 274: 568-573

2 Durham J W, Caster K E. Science, 1963, 140: 820-822

3 Shu D G, Conway Morris S, Han J, et al. Nature, 2004, 430: 422-428

4 Zhao Y L, Huang Y Z, Gong X Y. Acta Palaeontol Sin, 1994, 33: 305-324

5 Zhao Y L. The Kaili Biota: Marine Organisms from 508 Million Years ago (in Chinese). Guiyang: Guizhou Scientific Press, 2011. 1-251

6 Peng J, Zhao Y L, Wu Y S, et al. Chin Sci Bull, 2005, 50: 1159-1162

7 Zhao Y L, Parsley R, Peng J. Palaeogeogr Palaeoclimat Palaeoecol, 2007, 254: 317-327

$8 \mathrm{Hu}$ S X, Luo H L, Hou S G, et al. Chin Sci Bull, 2007, 52: 717-719

9 Luo H L, Li Y, Hu S X, et al. Early Cambrian Malong Fauna and Guanshan Fauna From Eastern Yunnan, China (in Chinese). Kunming: Yunnan Scientific Press, 2008. 1-134

10 Sprinkle J, Parsley R L, Zhao Y L, et al. J Paleontol, 2011, 85: 250-255

11 Lu Y H, Zhu Z L, Qian Y Y, et al. Correlation Chart of Cambrian in China with Explanation (in Chinese). Beijing: Science Press, 1982. $1-120$

12 Peng S C. Acta Palaeontol Sin, 2009, 48: 437-452

13 Peng S C. Chin Sci Bull, 2009, 54: 4161-4170

14 Zhang W T, Lu Y H, Zhu Z L, et al. Cambrian Trilobite Faunas from Southwest China (in Chinese). Beijing: Science Press, 1980. 1-497

15 Zhang X L, Hua H. Geol Mag, 2005, 142: 699-709

16 Lin J P, Ausich W I, Zhao Y L. Palaeogeogr Palaeoclimat Palaeoecol, 2008, 258: 213-221

17 Briggs D E G, Erwin D H, Collier F J. The Fossils of the Burgess Shale. Washington: Smithsonian Institution Press, 1994. 1-256

18 Lin J P, Ausich W I, Zhao Y L, et al. Geol Mag, 2008, 145: 17-36

19 Zhang Z Q. Cambrian-Ordovician. In: Zhang Z Q, Liu W M, eds. Lithostratigraphy of Shandong Province (in Chinese). Wuhan: China University of Geosciences Press, 1996. 1-328

20 Endo R, Resser C E. Bull Manchurian Sci Mus, 1937, 1: 1-406

21 Lin T R. Acta Palaeontol Sin, 1995, 34: 505-508

22 Wang Y N, Huang D Y, Lieberman B S. Acta Palaeontol Sin, 2010, 49: 101-109

Open Access This article is distributed under the terms of the Creative Commons Attribution License which permits any use, distribution, and reproduction in any medium, provided the original author(s) and source are credited. 